\title{
A Qualitative Study of Ramadan: A Month of Fasting, Family, and Faith
}

\author{
Zahra Alghafli ${ }^{1}$, Trevan G. Hatch ${ }^{2}{ }^{(1}$, Andrew H. Rose ${ }^{3}$, Mona M. Abo-Zena ${ }^{4}$, \\ Loren D. Marks ${ }^{2, *}$ and David C. Dollahite ${ }^{2}$ \\ 1 Rwabi Al-Khaleej Counseling Center, Dammam 31482, Saudi Arabia; zalgha1@hotmail.com \\ 2 School of Family Life, Brigham Young University, Provo, UT 84602, USA; trevan_hatch@byu.edu (T.G.H.); \\ david_dollahite@byu.edu (D.C.D.) \\ 3 Department of Sociology, Anthropology, \& Social Work, Texas Tech University, Box 41012, Lubbock, \\ TX 79409-1012, USA; andrew.rose@ttu.edu \\ 4 College of Education and Human Development, University of Massachusetts Boston, MA 02125, USA; \\ Mona.abozena@umb.edu \\ * Correspondence: loren_marks@byu.edu
}

Received: 21 January 2019; Accepted: 31 January 2019; Published: 19 February 2019

\begin{abstract}
Islam is a major world religion and the Muslim population is one of the fastest growing religious populations in the Western world, including in the United States. However, few research studies have examined the lived religious experience of U.S. Muslim families. Much of the attention on Islam among researchers and the media tends to be on controversial aspects of the religion. The purpose of this paper is to examine the unique religious practice of the month-long fast of Ramadan, especially its perceived role on marital and familial relationships from an insider's perspective. Content analysis of in-depth, qualitative interviews of twenty diverse Shia and Sunni Muslim families living in the United States ( $\mathrm{N}=47$ individuals) yielded several emergent themes. This study presents and explores data on the focal theme: "fasting brings us closer together." These data suggest that Ramadan serves a sacred, unifying, and integrating purpose for many of the 47 practicing Muslim mothers, fathers, and youth in this study. Meanings and processes involved in Ramadan and family relationships are explored and explained. Implications and applications of the research findings are discussed and some potential directions for future research are outlined.
\end{abstract}

Keywords: Ramadan; Muslim families; religion; fasting; Islam; qualitative

\section{Introduction}

Islam is one of the world's fastest growing religions and observing Ramadan marks one of the five pillars of the faith, yet there is little scholarly focus on the Ramadan experience in psychology or family studies journals (Alghafli et al. 2014a). In this article, based on in-depth, face-to-face interviews with Muslim families living in the United States, we provide a focused look at the utility, meaning, and power of the month-long fast of Ramadan for wives, husbands, and children based on their own firsthand reports. The article appears to be one of the first to closely examine this unique religious practice through the application of qualitative research methods to families.

The month of Ramadan refers to the ninth month of the Islamic calendar when "accountable" (i.e., post-puberty) Muslims fast during daylight hours. Per Islamic law, those who are ill, elderly, pregnant, breastfeeding, menstruating, or traveling are not obligated to completely abstain from food, drink, and sexual activity while fasting, but all other Muslims are exhorted to engage in the Ramadan fast (Alghafli et al. 2014b). 
O you who believe! Fasting is prescribed for you as it was prescribed for those before you, that you may become Al-Muttaqun (the pious). (Fasting) for a fixed number of days, but if any of you is ill or on a journey, the same number (should be made up) from other days. And as for those who can fast with difficulty, (i.e., an old man, etc.), they have (a choice either to fast or) to feed a poor person (for every day). But whoever does good of his own accord, it is better for him. And that you fast, it is better for you if only you know. (Quran 2:183-84; Khan 1971)

Indeed, fasting during the month of Ramadan is prescribed and exhorted as one of the Five Pillars of Islam - a foundation of the Muslim faith (Alghafli et al. 2014a). Ramadan, for many practicing Muslims, is the most sacred time of the year, a time that is devoted to enriching spirituality in several ways, including reading the Quran, saying additional prayers (salat), and reciting supplications (Ziaee et al. 2006, pp. 409, 411). Islamic teachings are primarily derived from the Quran, and the compilations of the sayings (hadith) of Prophet Muhammad PBUH.

Abu Hurayrah reported that the Messenger of Allah (peace and blessings be upon him) said: Every action a son of Adam does shall be multiplied-a good action by ten times its value, up to 700 times. Allah says: With the exception of fasting, which belongs to Me, and I reward it accordingly. For, one abandons his desire and food for My sake.

There are two occasions of joy for a fasting person: one when he breaks his fast, and the other when he meets his Lord, and the (bad) breath (of a fasting person) is better in the sight of Allah than the fragrance of musk. (Malik n.d., 18:58)

Ideally, Ramadan serves as a religious catalyst for individuals to refine their behaviors and improve their relationships with both Allah and those with whom they interact most closely, including and especially, family.

We will briefly overview three bodies of literature: (a) social science research on religion and family life, (b) social science research on religious practice among Muslims and Muslim Families, and (c) a contextualizing overview of Ramadan. The first body of literature includes hundreds of studies, while research on the latter two topics is meager at best.

\section{Social Science Research on Religion and Family Life}

Some emergent findings regarding the religion-health connection at the individual level are relatively striking (e.g., 7.6 year longevity increases among those who attend worship services more than weekly (Hummer et al. 1999, pp. 277-78)); cancer rates at half the prevalence of the general population for some actively religious groups, including members of The Church of Jesus Christ of Latter-day Saints who-like Muslims-integrate significant fasting into their lives (Enstrom 1998).

Empirical findings relating to what Darwin Thomas has called "the religion and family connection" tend to be less dramatic in scope and magnitude than those identified between religious involvement and physical health, but several modest connections have been identified (Marks and Dollahite 2017, p. 1). For example, in a prominent study of eight aspects of father involvement in relation to religion, sociologist Valerie King (2003) found that: "influence of religiousness on father involvement is generally modest and should not be overstated.... Nevertheless, certain aspects of father involvement are more frequent among the more religious, including better quality relationships ... and stronger feelings of obligation for contact with children" (p. 392).

King's findings related to the potential influences of "religiousness" on the father involvement are similar to those in scores of other social science studies examining different aspects of religion and family relationships (see Bengtson et al. (2013), for a discussion of mother and father influence across time). Correlations between religious involvement and salutary outcomes in family relationships are generally positive and generally small to moderate in magnitude-as observed by numerous scholars who have reviewed the religion and family literature across the past 25+ years (Burr et al. 2012; Koenig 
et al. 2001; Koenig et al. 2012; Mahoney 2010; Mahoney et al. 2001; Marks 2006; Marks et al. 2011; Thomas and Cornwall 1990). Even so, recurring findings over the past two to three decades include: (1) significantly lower divorce rates among same-faith married couples (Bahr 1981; Call and Heaton 1997; Lehrer and Chiswick 1993; Lehrer 2009); (2) relatively high reported marital satisfaction and/or fidelity rates (particularly among same-faith marriages), as noted in both quantitative-focused studies and reviews (Bahr and Chadwick 1985, pp. 411-13; Dollahite et al. 2004; Marks et al. 2011; Thomas and Cornwall 1990), as well as qualitative-based reports (Lambert and Dollahite 2006; Lu et al. 2013; Kaslow and Robison 1996; Robinson 1994; Robinson and Blanton 1993); and (3) the typically positive influence of rituals and sacred practices (including prayer, scripture study, etc.) on both marital and parent-child relationships (Dudley and Kosinski 1990; Fiese et al. 1993, 2002; Fiese and Tomcho 2001; Mahoney et al. 2001, pp. 583-87; Marks 2004; Marks and Dollahite 2012; Spagnola and Fiese 2007; for exceptions related to compulsory family worship, see Burr et al. 2012, pp. 118-19; Lee et al. 1997). This latter finding related to sacred family practices as an opportunity to promote positive family cohesion is of relevance in connection with the present article's focus on Ramadan. As scholars have observed, however, the samples in most extant studies are predominantly, even overwhelmingly, Christian and racially White, while relatively little is known about religious and racial/ethnic minority families, including Muslims (Alghafli et al. 2014a, pp. 814-15; Marks and Dollahite 2011). ${ }^{1}$

Additionally, in spite of the growing body of empirical research on the religion and family connection, social scientists still know relatively little about the deeper whys, hows, and processes at work behind the "sacred matters" (Burr et al. 2012; Marks and Dollahite 2011; Pargament and Mahoney 2005). One leading family scholar, Bill Doherty, has theorized that three dimensions-inclusion, control and intimacy - lie at the heart or "core" of healthy family interactions (Doherty et al. 1991, p. 227). Marks, Dollahite, and Hatch (Marks et al. 2017) have noted each of these dimensions at work in the sacred family practice of Shabbat among Jewish families, opening the door to questions regarding possible parallels in other faiths, including Islam.

Unfortunately, empirical research and/or scholarly evidence that conveys deeper insight and awareness regarding connections between religious practices and family relationships for Muslim families is scarce (Alghafli 2015). More specifically, there is a dearth of empirical social science literature that sheds light on practicing Muslim families living in the United States, though some work is emerging (see Alghafli et al. 2014b, 2017; Britto and Amer 2007; Franceschelli and O'Brien 2014; Hatch et al. 2017). First, however, we offer a brief overview of the extant research on Muslims and Muslim families, most of which is based on non-U.S. samples.

\subsection{Social Science Research on Muslims and Muslim Families}

A considerable portion (about $23 \%$ ) of the earth's population reportedly ascribes to the religion of Islam (Pew 2017b). Islam has been a major force in human history for nearly one-and-a-half millennia, particularly in the Eastern hemisphere (Alghafli et al. 2014b, p. 815). In recent years, Islam is becoming more prominent in several parts of the Western hemisphere as well (Abdullah 2007, p. 43; Pew 2017a). Indeed, a recent Pew (2017a) study projected that within the next three decades the global Muslim population will increase by $73 \%$ (compared to $35 \%$ of the world's population) and will go from 1.6 billion in 2010 ( $23 \%$ of global population) to 2.8 billion in 2050 ( $29.7 \%$ of the world's population), nearly matching the Christian population. The primary reason for this growth is higher fertility rates than in the general population in every region of the world where Muslims reside (Pew 2017a).

Estimates of the number of Muslims in America range from two to seven million, with perhaps the most rigorous data indicating 2.3 million (Pew 2007). According to Pew, about $63 \%$ of U.S. Muslims are first-generation immigrants (Pew 2011). Based on this data of Muslim growth worldwide, including

1 For notable book-length exceptions of research focused on racial minorities and religion, see (Taylor et al. 2004; Wilcox and Wolfinger 2016). 
in North America, the U.S. Muslim population cannot be ignored or marginalized as people who are distant and less relevant.

Despite the various countries of origin and ethnic backgrounds of many actively religious Muslim immigrants in the United States, they tend to hold similar religious beliefs and worldviews based on the Quran and the Prophet Mohammed's (Peace Be Upon Him (PBUH)) ${ }^{2}$ traditions. ${ }^{3}$ For many (and perhaps most) practicing Muslims, their religiously prescribed daily life is organized around their shared and sacred religious beliefs, practices, values, and rituals (Ghaffari and Çiftçi 2010). The larger question, however, remains: Does this pattern of involvement in Islamic belief and practice seem to make a measurable difference in the lives of individual persons?

Over the past decade, Abdel-Khalek, a professor of psychology at Kuwait University, has conducted a study examining the relationship between religiosity and subjective well-being, happiness, self-esteem, quality of life, and life satisfaction among Muslim populations. Since 2006, Abdel-Khalek's total sample size in ten related studies exceeds 17,000 participants from nations including Saudi Arabia, Qatar, Kuwait, Egypt, Palestine, Lebanon, and Algeria, as well as the United States. Abdel-Khalek's cross-national samples have included children, adolescents, and adults and have repeatedly found, across diverse samples, moderate correlations between higher levels of religiosity and more favorable subjective reports of happiness and well-being as well as better mental health (i.e., lower neuroticism, lower depression) and better physical health. In a separate study, Tiliouine, Cummins, and Davern (Tiliouine et al. 2009) explored the relationship between Muslim religiosity and a diverse range of life and health domains in a sample of 2909 Algerian males and females. Findings corroborated a positive relationship between religiosity and subjective well-being, as do at least three other studies (i.e., Hassouneh-Phillips 2001, 2003; Manganaro and Alozie 2011).

On a different note, multiple studies have found recurring and significant differences relating to gender, indicating better health for men versus women ${ }^{4}$ on both physical and mental health measures (Abdel-Khalek 2009, 2012; Abdel-Khalek and Eid 2011). While Abdel-Khalek's psychological studies are of significance and value, they address individual-level religiosity and well-being. Very few research studies have examined how Muslim practices influence familial and relational aspects of life. In summary, a dearth of empirical research on religious Muslim families remains-including families living in the United States (Alghafli 2015).

\subsection{Ramadan: A Brief Overview and Contextualization}

As previously mentioned, Ramadan, the ninth month of the Islamic calendar, is a time of fasting, which is one of the Five Pillars of Islam (the other Pillars include the creed or declaration of faith, prayer [salat], charity [zakat], and pilgrimage [haj] to Mecca at least once) (Alghafli et al. 2014b, p. 818). The month of fasting begins with the sighting of the new moon. During Ramadan, practicing Muslims do not eat or drink during daylight hours. While Ramadan usually calls to mind physical fasting from food, the fast is also to involve careful restraint from various temptations and also includes "fasting" or refraining from vain talk, expressing anger, and other behaviors that reflect lapses in moral composure. Abu Hurayrah reported that the Prophet (PBUH) said, "Fasting is a shield; so when one of

2 Consistent with usage among many Muslim scholars, and out of respect to our Muslim participants, when we refer to the founding prophet of Islam we include "PBUH" (Peace Be Upon Him).

3 Following Muhammad's (PBUH) death in 632 CE, the Umma (Muslim nation) split into two major factions: Shia Muslims and Sunni Muslims. Both agree on the main Islamic pillars involving the reality and nature of Allah (God) and Mohammad's prophetic calling and mission. Both branches pray five times a day (salat), fast during the daylight hours for one month every year (Ramadan), give money to the poor (zakat), and follow the same sacred book (The Quran). The two branches of Islam differ primarily in their views regarding the appropriate successor of Mohammed (for a more detailed discussion, see Alghafli et al. 2014b).

4 Another body of studies examines gender-role attitudes among Muslim women (Bartkowski and Read 2003; Piela 2010; Read 2003) and women's roles in society (Read 2002, 2004). 
you is fasting he should neither indulge in obscene language nor should he raise his voice in anger. If someone attacks him or insults him, let him say: 'I am fasting!'” (Muslim 1151, 13:212)

In fasting from food and drink following the sunset, it is customary for Muslims to eat a meal (suhoor) after the evening prayer (maghrib) (Glasse 1989, pp. 329-30). Those exempted from fasting include young children, menstruating women, the elderly, and the sick. Generally, children are introduced to fasting by incremental steps; they may start with a half day and then gradually increase to multiple days. Since the Islamic calendar is lunar, Ramadan is not tied to any particular season of the year, but shifts by approximately 11 days on the Gregorian calendar each year. Thus, fasting (including abstaining from fluids) during summer months where the days are longer and hotter presents different challenges than fasting during the winter months (Lewis and Churchill 2009).

Ramadan also requires abstaining from sexual activity during the (daytime) fast. When a person breaks their fast at sundown, they may engage in sexual activities with their spouse. Finally, in addition to the physical forms of discipline outlined, during Ramadan practicing Muslims tend to increase their religious observances like offering many supplementary prayers and engaging in intensive reading sessions of the Quran (Glasse 1989, pp. 329-30).

\section{Method}

The American Families of Faith research project, co-directed by the fifth and sixth authors of this article, is a national, qualitative study of 200 racially, religiously, and economically diverse families from all eight major geographic regions of the United States. In this project, we employ a strengths-based approach, studying "exemplar" (i.e., clergy-referred) families to garner information regarding healthy processes (Marks and Dollahite 2011). The present article is based on in-depth qualitative interviews with the Muslim subsample of the American Families of Faith project. ${ }^{5}$ In this method section, we will address issues including: (a) sample, (b) interview procedures, (c) data analysis, and (d) reflexivity, respectively.

\subsection{Sample}

We attended Muslim religious services and celebrations at various sites, and met with Muslim imams and leaders. We explained The American Families of Faith research project and requested help from leaders in these Muslim communities in obtaining interview referrals (and entrée) with families who were highly involved in the faith community and also seemed to have strong and happy marriages. In doing so, we engaged in purposive or prototypical sampling (Daly 2007, p. 175), striving to learn from families who had apparently high levels of success in combining their religious faith and family relationships.

The total sample for this article was 20 families $(\mathrm{N}=47$ individuals; 20 wives/mothers, 20 husbands/fathers, 7 adolescent offspring ${ }^{6}$. More specifically, there were 14 Sunni families and six Shia families. The combined sample was diverse in terms of: (a) adult age (early 30s to early 60s); (b) race/ethnicity (including African American, Arab (from Iraq, Jordan, and Palestine), Western European, Eastern European, Indian (India), Malaysian, and Iranian participants); and (c) socioeconomic status (education levels ranged from some high school to Ph.D./M.D. degrees). The Muslim families resided in five regions, including New England (MA); Mid-Atlantic (PA); Pacific (CA); Mid-West (OH), and Gulf Coast (LA) regions.

The seven adolescent offspring who participated in the interviews ranged from 10 to 20 (mean age $=16$ years). Adult participants had been married for a mean of about 19 years and were the parents of

5 See https://americanfamiliesoffaith.byu.edu.

6 Families averaged about four children each, but only seven adolescent children were interviewed due to limitations related to Internal Review Board (IRB) approval. 
at least one child between 2 and 18 years of age (Mean $=4$ children). This latter feature allowed us to examine parent-child relationships, in addition to marital relationships.

\subsection{Interview Procedures}

Interviews based on a semistructured questionnaire were conducted with each couple with both spouses present. No questions on the semistructured questionnaire directly addressed fasting. However, in response to questions asking about sacred practices that held special meaning for them, Muslim families frequently (and often passionately) discussed the importance of Ramadan, thereby making the present study possible.

The length of the interview varied from couple to couple, with an average time of about 90-120 min. With each question, both the wife and husband were given an opportunity to respond-and opportunity to respond first typically alternated with each question.

Life experiences and narratives were sought to add depth, richness, and color to the combined interview data. During the joint interviews, wives and husbands would often encourage each other, adding details, making corrections, and offering their alternative perspective. We do not believe that joint interviewing is the best approach to all (or even most) topics. Often it is desirable to interview family members independently for reasons including, but not limited to: fear of disclosure, power differential, moderating desirability effect, and fear of repercussion (Seymour et al. 1995). Indeed, some of our recent (but unrelated) work has sought to employ interviews with: (a) the wife individually, (b) the husband individually, and (c) the couple together (Plauche et al. 2016). ${ }^{7}$ With these important caveats noted, however, our overall experience was that for the focal topics at hand (family religious practices, strong marriage/family relationships), the approach of joint interviewing worked well, consistent with the experience and recommendation of previous researchers who have found that this approach can shed light on the different kinds of knowledge held by each spouse (Arksey 1996; Edgell 1980; Seymour et al. 1995). Conjoint interviewing can also produce clearer and more complete pictures as interviewees fill in each other's gaps and memory lapses (Seymour et al. 1995). In addition, joint interviewing offers (to the observant interviewer) insights into the nature of the relationship and connections between couples through observation of nonverbal communication (Arksey 1996).

\subsection{Qualitative Data Analysis}

Interviews were recorded and then transcribed verbatim. Files were then saved as Microsoft Word documents by researchers from the American Families of Faith project. The first author performed grounded theory-based open coding and axial coding independently (Strauss and Corbin 1998, pp. 101-42). She also compiled Numeric Content Analyses (NCA) of the predominant coded themes, noting how many total occurrences were documented within and across interviews (Marks 2015, pp. 496, 501). As a check for inter-rater reliability, two additional co-authors reviewed the coded interviews and the supporting thematic files composed of qualitative interview excerpts (that were documented by interview and page number). Seven major, emergent themes were identified by the first author and confirmed by the second and fifth authors. These efforts are consistent with the construction of a data audit trail exhorted by many qualitative researchers (Denzin and Lincoln 2000; Handel 1996; Marks 2015). A few of the central themes were presented in a recent article (Alghafli et al. 2014b). Another theme (meanings behind the Hijab or practice of veiling/covering in Islam) is discussed in another recent manuscript (Alghafli et al. 2017). In this article, we focus on a single theme but do so in depth: "Fasting brings us closer to each other." We now turn to the issue of reflexivity in qualitative research.

7 For more detailed discussion of this issue, see (Marks et al. 2008; Marks and Dollahite 2011). 


\subsection{Reflexivity}

Reflexivity refers to self-observation and skepticism in the process and results of the research (Anastas 1999, p. 7). In other words, it is "practicing bias regulation through bias recognition, rather than through the denial of bias" (Pieper 1989, p. 18). We agree with the practice of revealing biases and experiences that relate to the data being considered, and in the spirit of transparency and authenticity, we share relevant information next.

All five authors, like the adult participants in our study: (a) are in long-term marriages, (b) are parents, and (c) are religiously active and involved in both home and faith community settings. More specifically, the first author is a Muslim, a wife and mother. The fourth author is also a Muslim, a wife and mother. The second, third, fifth, and sixth authors are all members of The Church of Jesus Christ of Latter-day Saints, husbands and fathers. As a result, the authors combine to create a team with both insider and outsider perspectives, as recommended in recent work on qualitative methodology (Marks 2015, p. 498).

\section{Findings}

The salience of the Ramadan fast was raised frequently by both Sunni and Shia participants. In an effort to convey an authentic "insider perspective" via the participants' own voices, about 30 illustrative examples from the primary data are shared in connection with the focal theme of this article. That overarching theme, drawn from the participants' own words, is: "Fasting brings us closer to each other." Although this concept will serve as our focus in our Findings section, we address this overarching theme from three different vantage points. These are provided by Doherty and colleagues' (Doherty et al. 1991) "three core dimensions" involved in family rituals of inclusion, control, and intimacy. As adapted for the present study, the dimensions include: (a) Inclusion and Involvement of All Family Members in Ramadan, (b) Control, Discipline, and the Sacred Context of Ramadan, and (c) Intimacy, Unity, and Togetherness during Ramadan. These dimensions will be discussed respectively.

\subsection{Dimension 1: Inclusion and Involvement of All Family Members in Ramadan}

Muhammad, a Shia husband, mentioned that Ramadan is a pinnacle family event for him. When asked about the reasons why, he stated that during Ramadan, "We have more family discussion." For example, Muhammad mentioned that when breaking their fast, his family all talk with each other: "'How is your day? How are you doing?' and this and that, and then you sit and eat. We all break the fast together." Muhammed's wife, Alya, continued:

We all have to sit and eat. It is not like [one person says], 'I will eat now' [and another says], 'I will grab something later.' [No], we all sit down and eat [together].

Alya's emphasis on "sit[ting] down and eat[ing]" together is a concept to which we will return near the end of this article.

One Shia husband talked about Ramadan as a family time that everyone looks forward to, parents and children. He stated, "[Our] boys are looking towards Ramadan all year. We look forward to it as a family, we all fast together as a family."

A Sunni Muslim father named Ismail, like other participants, specifically discussed the Ramadan fast not as a practice or ritual but as an "experience" ... something a family all goes through "together every day."

Ismail (Sunni husband): [W] get up early, very early in the morning [to] have a meal together, like a breakfast. We have a meal together, and then after the meal, we read Quran, our scripture. And after we do that, it's time for prayer. We pray together ... [Then], in the evening (after sunset), which is the time of breaking [our] fast, again, the same thing happens as during the morning. We all come together as a family, and we eat together and we thank 
God together, we pray together. After [that] we break the fast. And then we do more prayers. So the whole month of Ramadan is a very unique experience. We do a lot less of the worldly things and a lot more of godly things than we normally do.... When you do those kinds of things together every day ... it ... bring[s] people together and it strengthens our beliefs and [our] family.

Ismail's description of the fast is permeated by words of unity-with "we," "together," and "family" occurring a composite of nearly 20 times. Indeed, the fact that Muslim families fast (and break their fast) at specific times and in unison seems to enrich family members' interactions and bonds.

Reports from Muhammad, Alya, and Ismail repeatedly underscore the importance of Dimension 1: Inclusion and Involvement of All Family Members in Ramadan. We now turn to Dimension 2.

\subsection{Dimension 2: Control, Discipline, and the Sacred Context of Ramadan}

Outsiders to Islam often marvel at the discipline required for a month-long fast. The Muslim participants in our study, however, more frequently emphasized the spiritual and/or relational discipline inherent in the sacred context of Ramadan. Many reported an emphasis on other (nondietary) behaviors that need extra attention and control during the sacred month.

Restricting the understanding of fasting in Islam to the literal definition, without accounting for the spirit of the practice, however, is an apparent oversimplification from the perspective of many of our participants. Muslim texts referencing the Prophet Mohammed (PBUH) state, "Whoever does not give up forged speech and evil actions, Allah is not in need of his leaving his food and drink (i.e., Allah will not accept his fasting)" (Al-Bukhari 1903, 30:13).

Some participants mentioned Ramadan as a sacred, spiritual journey that the whole family experiences together. One father shared his family's experience by explaining:

[Ramadan] is a very, very good experience for us. I think what fasting does is [that] it makes everything else so insignificant. Seeing the family, the marriage, human life-[these are] really the most important things in the world, because everything else means nothing, really. [During the year] we do get carried away with worldly things, the houses, the cars, and all of that, I think-[but Ramadan] really brings you right to the ground and [gets you] grounded with God.

For this father, fasting is foundational and "brings you right to the ground." Another father explained, "Ramadan has been prescribed to us where every Muslim is supposed to [fast]. It's one of the five pillars of Islam."

Noreen (a Sunni wife), while generally discussing the role of Islam in her marriage, mentioned fasting as an exemplary religious arrangement between herself and her husband that demands that they refrain from arguing. Noreen, like others, invoked "we" and "together" repeatedly in connection with Ramadan, but her language referred to the marital "we" of Noreen and her husband. She stated:

I think that religion affects our married life because in this point we can agree, and we spend some time without arguing. For example, when we both fast, we do our activities together. We break the fast together [and] we wake up midnight and eat before fasting. So we do these types of things together.... At this point we again agree and that's how religion is making our life, going together and growing together.

In the above excerpt by Noreen, she began by mentioning "arguing" between herself and her husband, and then she alternatively referenced harmonious times she and her husband spend together during Ramadan - with an emphasis on the religious activities they participate in together. In these few lines, Noreen uses the word "agree" twice and "together" five times when talking about her marriage in connection with fasting. We note that Noreen begins her response by using the first person singular 'I,' but then shifts to the plural and marital 'we,' which she uses at least eight times in four lines. In other words, Noreen is not only emphasizing the importance of control and discipline in her 
marital conversations during Ramadan, she is also emphasizing unity and togetherness in marital and family relations. Having addressed Dimension 2: Control, Discipline, and the Sacred Context of Ramadan, we next turn to the latter phenomenon of interest raised by Noreen, unity. Indeed, Intimacy, Unity, and Togetherness are the foci of our third and final dimension, discussed next.

\subsection{Dimension 3: Intimacy, Unity, and Togetherness during Ramadan}

In almost every interview in which Ramadan ${ }^{8}$ was mentioned, both the wife and husband, often with animation and excitement, talked about the fast as a time when family members get closer to each other than perhaps at any other time.

Gulam $^{9}$ (Sunni husband): The thing that we really enjoy and cherish is the month of Ramadan because we do so many things together as a family. We wake up in the middle of the night. We sit together, we eat together, and we pray together. [We] go to [mosque] and bring food. And we get together as a family.

In five brief sentences, Gulam uses the word "family" twice, "together" five times, and the family-referencing pronoun "we" eight times-a total of 15 allusions to family unity.

Noreen emphasized the marital harmony she associates with Ramadan. Alya focused on the familial unity that is promoted. Alya's husband Muhammad agreed with his wife about the salience of Ramadan, explaining that for him:

It is really the first day [of Ramadan] that gets me the most, for some reason. I do not know [why]. The first day of Ramadan [to me, means] more than ... any other day of the year. The first day of Ramadan is important to me.... The first month that my daughter had to fast and at the end of the day, we were sitting next to each other, that was the best. I was proud of her.

Muhammed's reflections identify additional benefits of the Ramadan fast; the literal physical and emotional closeness of parent and child, father and daughter, and a resulting sense of paternal pride. Muhammad presents Ramadan in a way that seems to strengthen the familial circle.

Each of the narratives presented reflect the participants' lived experiences and their perceived associations between the shared Ramadan fast and heightened levels of unity, closeness, and warmth in the participants' family lives and relationships. Indeed, participants report that Ramadan binds family members emotionally and draws them closer to each other, physically and spiritually.

In addition to the consideration of Ramadan as a sacred month where Muslims are encouraged to improve their religious beliefs and practices, the sacred month of fasting seems to literally and figuratively set the table for more pure, more peaceful, and more meaningful family interactions.

Even though fasting is a physical and mental challenge and a sacrifice, the reported individual and family-level benefits and the long-term rewards of this shared and sacred family practice appear to be worth the challenges and costs in the lives of most of the Muslim participants we interviewed. As sociologists of religion Stark and Finke (2000) note: "[P]eople will only accept high religious costs if these result in such high levels of religious benefits that the [overall] result is a favorable exchange ratio. [In sum], people attend not only to cost, but to value in making their decisions (p. 51). Indeed, for many of the Muslim families we interviewed, the Ramadan fast seems to embody the essence of a 'high-cost but high-value' sacred family practice" (Marks et al. 2009, p. 15).

As discussed previously, in an influential article 25 years ago, Doherty, Colangelo, and Hovander (Doherty et al. 1991) posited that "three core dimensions of family interaction-inclusion, control and intimacy —constitute an optimal priority sequence for managing ... stressful experiences" (p. 227,

8 Muslim participants frequently used the words Ramadan and fasting interchangeably.

9 All names are pseudonyms to protect anonymity. 
emphasis added). As in our American Families of Faith work with family-level religious practices with other groups (Marks et al. 2017; Marks et al. 2008), Doherty's "three core dimensions" repeatedly arose in our Muslim participants' reflections regarding their Ramadan celebrations, which involved: (a) the inclusion of all family members, (b) the structured control and predictability of consistent rituals that add stability and reduce chaos, and (c) the resulting closeness, unity, "we-ness," and intimacy between spouses, as well as between parents and children. As we conclude the Findings section, we present a final narrative excerpt with all three core dimensions in mind:

Maryam (Shia wife): I think my children, my husband, and I [inclusion: "we" = wife, husband, children]—altogether at the same time-we are trying to control ourselves and avoid doing some things. It is like we are playing a game together and when you are playing a game with other friends, you have fun with them.... We are breaking our fast together [control/structure: a set time, a set place, a set table] and we think, "Oh, all of us are playing a game, ahhh!" [The breaking of the fast] gets us closer to each other [intimacy: "fast together," relational closeness].

Maryam, like others earlier, injects several (p. 10) collectivist terms (e.g., "altogether," "we," "together," and "us") into a few brief lines, emphasizing the reportedly pervasive unity inspired by Ramadan. For Maryam and her family, it seems that Ramadan is a sacred practice that integrates inclusion and a sense of control/structure that promotes intimacy in ways that reflect the optimal pattern of family interaction promoted by Doherty and colleagues.

In the broader American Families of Faith project, we have found similar patterns in other religious families (e.g., Shabbat in observant Jewish families (Marks et al. 2017), but based on the participants' reports, Ramadan serves a sacred, unifying, integrating purpose for many of the 47 practicing Muslim mothers, fathers, and children in this study.

\section{Discussion}

This study, first and foremost, aims to add the voices and perspectives of practicing, highly religious U.S. Muslims so that prevalent, media-based images are supplemented by systematic, empirically grounded research. More specifically, beyond examining the importance of religion in the lives of these families, this study attempts to explore and explain why and how fasting, as a lived religious practice, matters to the participants.

There are important lessons to be learned from strong, healthy families from minority religions because they, of necessity, have built family strength without the support of the cultural mainstream-perhaps even overcoming antipathy in order to thrive. Unfortunately, rather than examine these families as potential models of strength, the experience of antipathy of lived religion has too often carried into various settings. This study extends the invitation to learn from strengths and to avoid antipathy.

For Muslim individuals and families, although Ramadan is a time of meaning, unity, and shared faith, the month-long fast is full of challenges and hardships (Alghafli 2015). Not eating and drinking for $10 \mathrm{~h}$ or more per day is difficult and requires restraint and discipline, particularly for Muslims who live in non-Muslim countries and are surrounded by people who eat and drink in shared work and school environments throughout the 30 days of the fast.

Even so, the participants indicated their perceptions that fasting as a religious practice tends to connect and unite family members. This connection seems to assist participants during crisis and hardships, as they feel protected, cared for, and surrounded by "mercy" and "blessings." This finding seems to be consistent with other research literature addressing sacred rituals and practices that are home-based and/or which involve the whole family (Doherty 2002; Marks and Dollahite 2012) and is in line with the Hadith, Narrated by Abu Huraira: Allah's Messenger (PBUH) said, "When the month of Ramadan starts, the gates of the heaven are opened and the gates of Hell are closed and the devils are chained." (Al-Bukhari 1903, 30:13) 


\subsection{Limitations and Directions for Future Research}

The focus of the present study on Ramadan has been almost exclusively on family relationships. There are likely profound, individual-level effects, challenges, and influences associated with Ramadan-personal meaning making - that lie outside of this study's family-focused purview. However, individual-level and psychological influences associated with Ramadan warrant close attention as well. Additionally, the present piece does not address the important sociological element of faith community and the collectivistic and sacred role of the masjid (mosque) during Ramadan. The present study's failure to convey the richness of faith community context should not be interpreted as a signal that the masjid was unimportant to these families. In other words, this article's focus on family was intended to convey, with specificity and depth, a portion of the broader constellation of Islam; a constellation that includes family but also involves: (1) personal, introspective, and psychological elements of Ramadan; and (2) sociological, communal, and masjid-based elements of Ramadan. We recommend that future research address both the intrapersonal and the sociological, offering value-added perspectives to familial and relational foci of this article.

\subsection{Implications and Applications}

Being aware of the influence these practices have in the lives of Muslim families can provide great benefit for educators, counselors, and therapists who are seeking to better understand and to effectively assist practicing Muslim couples and families. Furthermore, the current study can enrich religious leaders within the Muslim community with more information about family life, marriage, and parent-child relationships, as these leaders often serve as counselors, and as a main source of information and advice in Muslim religious communities (Abdullah 2007, p. 44). While the present sample was purposive and not generalizable, the likelihood is high that Islam as a lived religion and, specifically, Ramadan as a shared and sacred family practice are similarly influential and vital in the lives and families of many other U.S. Muslims.

Additionally, while the family foundation is certainly important, many Muslims are also highly connected with the ways fasting has connected Muslims over generations, currently across time and space (when/where practicing Muslims start and stop at the same relative time of the day, irrespective of location). Further, in addition to the self-discipline and sacrifice for Allah made by this private act of worship and resulting connection, fasting also reportedly promotes empathy with the poor. Indeed, the Ramadan fast concludes with the practice of $z a k a t^{10}$ ) (the pillar of alms-giving and charity) that exhorts able Muslims to give one fortieth or $2.5 \%$ of their non-essential wealth (Marks et al. 2009).

Quantitative survey and poll-based research data indicate that the Muslim population in the United States continues to grow, both in raw numerical strength and in percentage of the overall population (Pew 2017a). Further, nearly two-thirds (63\%) of all U.S. Muslims are first-generation immigrants who are only commencing their family stories and family expansion on Western ground and in Western culture (Pew 2011). Zaid bin Khalid Al-Juhani narrated that: The Messenger of Allah said: "Whoever provides the food for a fasting person to break his fast with, then for him is the same reward as his (the fasting person's), without anything being diminished from the reward of the fasting person." (At-Tirmidhi 807) For a variety of reasons, including this multiplicative one, how Muslim individuals and families interact with others and bring together people at the table continues to expand. At the front end of this time of transition and change, it becomes increasingly important to have a deeper and, ideally, a quantitatively and qualitatively enhanced awareness of what lies at or near the center of meaning and function for many of these individuals and families.

10 There is a different (lesser) zakat that is made before Eid ul Fitr prayer. This is Zakt ul fitr and is usually the equivalent of the price of one meal in the area where the giver is living (religious leaders set the price in each region) or about $\$ 10$ per each member of the household (including babies and elderly or people who aren't obligated to fast). This is then distributed to the poor so that all may enjoy the breaking of the fast with a meal. 
Author Contributions: Conceptualization, Z.A., T.G.H., and L.D.M.; methodology, Z.A., T.G.H., D.C.D., and L.D.M.; software, T.G.H.; validation, T.G.H., M.M.A.-Z., and L.D.M.; formal analysis, Z.A., T.G.H., and L.D.M.; investigation, Z.A., T.G.H., D.C.D., and L.D.M.; resources, Z.A., T.G.H., A.H.R., M.M.A.-Z., D.C.D., and L.D.M.; data curation, Z.A., T.G.H., D.C.D., and L.D.M.; writing-original draft preparation, Z.A., T.G.H., and L.D.M.; writing-review and editing, A.H.R., M.M.A.-Z., and D.C.D.; project administration, D.C.D., and L.D.M.; funding acquisition, D.C.D., and L.D.M.

Funding: Loren D. Marks and David C. Dollahite express thanks to the Eliza R. Snow Fellowship at BYU for generous support of the American Families of Faith research project. The present article is based on the Strong Muslim Families branch of that project.

Conflicts of Interest: The authors declare no conflicts of interest.

\section{References}

Abdel-Khalek, Ahmed. 2009. Religiosity, Subjective Well-Being, and Depression in Saudi Children and Adolescents. Mental Health, Religion \& Culture 12: 803-15.

Abdel-Khalek, Ahmed. 2012. Associations between Religiosity, Mental Health, and Subjective Well-Being among Arabic Samples from Egypt and Kuwait. Mental Health, Religion E Culture 15: 741-58.

Abdel-Khalek, Ahmed M., and Ghada K. Eid. 2011. Religiosity and Its Association with Subjective Well-Being and Depression among Kuwaiti and Palestinian Muslim Children and Adolescents. Mental Health, Religion $\mathcal{E}$ Culture 14: 117-27.

Abdullah, Somaya. 2007. Islam and Counseling: Models of Practice in Muslim Communal Life. Journal of Pastoral Counseling 42: 42-55.

Al-Bukhari, Sahih. 1903. Book 30, Hadith 13. Available online: https://sunnah.com/bukhari/30/13 (accessed on 12 February 2019).

Alghafli, Zahra. 2015. Familial Relationships among Muslim Couples and Parents in the U.S.: A Qualitative Study. Ph.D. dissertation, Louisiana State University, Baton Rouge, LA, USA.

Alghafli, Zahra, Trevan G. Hatch, and Loren D. Marks. 2014a. Islam. In The Social History of the American Family. Edited by Marilyn J. Coleman and Lawrence H. Ganong. Thousand Oaks: Sage, pp. 769-72.

Alghafli, Zahra, Trevan G. Hatch, and Loren D. Marks. 2014b. Religion and Relationships in Muslim Families: A Qualitative Examination of Devout Married Muslim Couples. Religions 5: 814-33. [CrossRef]

Alghafli, Zahra, Loren D. Marks, Trevan G. Hatch, and Andrew H. Rose. 2017. Veiling in Fear or in Faith? Meanings of the Hijab to Practicing Muslim Wives and Husbands in USA. Marriage E Family Review 53: 696-716.

Anastas, Jeane W. 1999. Research Design for Social Work and the Human Sciences, 2nd ed. New York: Columbia University Press.

Arksey, Hilary. 1996. Collecting Data through Joint Interviews. Social Research Update 15: 1-4.

At-Tirmidhi, Jami. 807. Book 8, Hadith 126. Available online: https://sunnah.com/tirmidhi/8/126 (accessed on 12 February 2019).

Bahr, Howard M. 1981. Religious Intermarriage and Divorce in Utah and the Mountain States. Journal for the Scientific Study of Religion 20: 251-61. [CrossRef]

Bahr, Howard M., and Bruce A. Chadwick. 1985. Religion and Family in Middletown, USA. Journal of Marriage $\mathcal{E}$ Family 47: 407-14.

Bartkowski, John P., and Jennan G. Read. 2003. Veiled Submission: Gender, Power, and Identity among Evangelical and Muslim Women in the United States. Qualitative Sociology 26: 71-92. [CrossRef]

Bengtson, Vern L., Norella M. Putney, and Susan Harris. 2013. Families and Faith: How Religion is Passed Down Across Generations. New York: Oxford.

Britto, Pia Rebello, and Mona M. Amer. 2007. An Exploration of Cultural Identity Patterns and the Family Context among Arab Muslim Young Adults in America. Applied Developmental Science 11: 137-50. [CrossRef]

Burr, Wesley R., Loren D. Marks, and Randal D. Day. 2012. Sacred Matters: Religion and Spirituality in Families. New York: Routledge/Taylor \& Francis Group.

Call, Vaughn R. A., and Tim B. Heaton. 1997. Religious Influence on Marital Stability. Journal for the Scientific Study of Religion 36: 382-92. [CrossRef]

Daly, Kerry J. 2007. Qualitative Methods for Family Studies and Human Development. Thousand Oaks: Sage. 
Denzin, Norman K., and Yvonna S. Lincoln, eds. 2000. Handbook of Qualitative Research, 2nd ed. Sage: Thousand Oaks.

Doherty, William J. 2002. The Intentional Family: Simple Rituals to Strengthen Family Ties. New York: Quill.

Doherty, William J., Nicholas Colangelo, and Deborah Hovander. 1991. Priority Setting in Family Change and Clinical Practice: The Family FIRO Model. Family Process 30: 227-40. [CrossRef]

Dollahite, David C., Loren D. Marks, and Michael A. Goodman. 2004. Religiosity and Families: Relational and Spiritual Linkages in a Diverse and Dynamic Cultural Context. In The Handbook of Contemporary Families: Considering the Past, Contemplating the Future. Edited by Marilyn J. Coleman and Lawrence H. Ganong. Thousand Oaks: Sage, pp. 411-31.

Dudley, Margaret G., and Frederick A. Kosinski Jr. 1990. Religiosity and Marital Satisfaction: A Research Note. Review of Religious Research 32: 78-86. [CrossRef]

Edgell, Stephen. 1980. Middle-Class Couples. London: George Allen and Unwin.

Enstrom, James E. 1998. Health Practices and Cancer Mortality Rates among Active California Mormons. In Latter-Day Saint Social Life: Social Research on the LDS Church and its Members. Edited by James T. Duke. Salt Lake City: Bookcraft, pp. 441-60.

Fiese, Barbara H., and Thomas J. Tomcho. 2001. Finding Meaning in Religious Practices: The Relation between Religious Holiday Rituals and Marital Satisfaction. Journal of Family Psychology, Families and Religion 15: 597-609. [CrossRef]

Fiese, Barbara H., Karen A. Hooker, Lisa Kotary, and Janet Schwagler. 1993. Family Rituals in the Early Stages of Parenthood. Journal of Marriage and the Family 55: 633-42. [CrossRef]

Fiese, Barbara H., Thomas J. Tomcho, Michael Douglas, Kimberly Josephs, Scott Poltrock, and Tim Baker. 2002. A Review of 50 Years of Research on Naturally Occurring Family Routines and Rituals: Cause for Celebration? Journal of Family Psychology, Family Routines and Rituals 16: 381-90. [CrossRef]

Franceschelli, Michela, and Margaret O'Brien. 2014. 'Islamic Capital' and Family Life: The Role of Islam in Parenting. Sociology 48: 1190-206. [CrossRef]

Ghaffari, Azadeh, and Ayşe Çiftçi. 2010. Religiosity and Self-Esteem of Muslim Immigrants to the United States: The Moderating Role of Perceived Discrimination. International Journal for the Psychology of Religion 20: 14-25. [CrossRef]

Glasse, Cyril. 1989. Ramadan. In The Concise Encyclopedia of Islam. London: Stacey International, pp. 329-30.

Handel, Gerald. 1996. Family Worlds and Qualitative Family Research: Emergence and Prospects of Whole-Family Methodology. Marriage \& Family Review 24: 335-48.

Hassouneh-Phillips, Dena. 2001. Polygamy and Wife Abuse: A Qualitative Study of Muslim Women in America. Health Care for Women International 22: 735-48. [CrossRef]

Hassouneh-Phillips, Dena. 2003. Strength and Vulnerability: Spirituality in Abused American Muslim Women's Lives. Issues in Mental Health Nursing 24: 681-94. [CrossRef] [PubMed]

Hatch, Trevan, Zahra Alghafli, Loren Marks, Andrew Rose, Jennifer Rose, Benjamin Hardy, and Nathaniel Lambert. 2017. Prayer in Muslim Families: A Qualitative Exploration. Journal of Religion E Spirituality in Social Work: Social Thought 36: 73-95.

Hummer, Robert A., Richard G. Rogers, and Charles B. Nam. 1999. Religious Involvement and U.S. Adult Mortality. Demography 36: 273-85. [CrossRef] [PubMed]

Kaslow, Florence, and James A. Robison. 1996. Long-Term Satisfying Marriages: Perceptions of Contributing Factors. American Journal of Family Therapy 24: 153-70. [CrossRef]

Khan, Muhammad M. 1971. Sahih Bukhari: Translation of the Meaning of the Quran. Saudi Arabia: Almadina Islamic University.

Koenig, Harold G., Michael E. McColleugh, and David B. Larson, eds. 2001. Handbook of Religion and Health, 1st ed. New York: Oxford University Press.

Koenig, Harold G., Dana E. King, and Verna Benner Carson, eds. 2012. Handbook of Religion and Health, 2nd ed. New York: Oxford University Press.

King, Valarie. 2003. The Influence of Religion on Fathers' Relationships with Their Children. Journal of Marriage and Family 65: 382-95. [CrossRef]

Lambert, Nathaniel M., and David C. Dollahite. 2006. How Religiosity Helps Couples Prevent, Resolve, and Overcome Marital Conflict. Family Relations: An Interdisciplinary Journal of Applied Family Studies 55: 439-49. [CrossRef] 
Lee, Jerry W., Gail T. Rice, and V. Bailey Gillespie. 1997. Family Worship Patterns and Their Correlation with Adolescent Behavior and Beliefs. Journal for the Scientific Study of Religion 36: 372-81. [CrossRef]

Lehrer, Evelyn. L. 2009. Religion, Economics, and Demography. New York: Routledge.

Lehrer, Evelyn L., and Carmel U. Chiswick. 1993. Religion as a Determinant of Marital Stability. Demography 30: 385-404. [CrossRef] [PubMed]

Lewis, Bernard E., and Buntzie E. Churchill. 2009. Islam: The Religion and the People. Upper Saddle River: Wharton School Publishing.

Lu, Yaxin, Loren D. Marks, Olena Nesteruk, Michael Goodman, and Loredana Apavaloaie. 2013. Faith, Conversion, and Challenge: A Qualitative Study of Chinese Immigrant Christian Marriage (in the USA). Journal of Comparative Family Studies 44: 227-47. [CrossRef]

Mahoney, Annette. 2010. Religion in Families, 1999-2009: A Relational Spirituality Framework. Journal of Marriage and Family 72: 805-27. [CrossRef]

Mahoney, Annette, Kenneth I. Pargament, Nalini Tarakeshwar, and Aaron B. Swank. 2001. Religion in the Home in the 1980s and 1990s: A Meta-Analytic Review and Conceptual Analysis of Links between Religion, Marriage, and Parenting. Journal of Family Psychology, Families and Religion 15: 559-96. [CrossRef]

Malik, Muwatta. n.d. Book 18, Hadith 58. Available online: https://sunnah.com/urn/406940 (accessed on 12 February 2019).

Manganaro, Lynne L., and Nicholas O. Alozie. 2011. Gender Role Attitudes: Who Supports Expanded Rights for Women in Afghanistan? Sex Roles: A Journal of Research 64: 516-29. [CrossRef]

Marks, Loren. 2004. Sacred Practices in Highly Religious Families: Christian, Jewish, Mormon, and Muslim Perspectives. Family Process 43: 217-31. [CrossRef] [PubMed]

Marks, Loren. 2006. Religion and Family Relational Health: An Overview and Conceptual Model. Journal of Religion and Health 45: 603-18. [CrossRef]

Marks, Loren. 2015. A Pragmatic, Step-by-Step Guide for Qualitative Methods: Capturing the Disaster and Long-Term Recovery Stories of Katrina and Rita. Current Psychology: A Journal for Diverse Perspectives on Diverse Psychological Issues 34: 494-505. [CrossRef]

Marks, Loren D., and David C. Dollahite. 2011. Mining the Meanings and Pulling out the Processes from Psychology of Religion's Correlation Mountain. Psychology of Religion and Spirituality 3: 181-93. [CrossRef]

Marks, Loren D., and David C. Dollahite. 2012. "Don't Forget Home": The Importance of Sacred Ritual in Families. In Understanding Religious Rituals. Edited by John P. Hoffman. New York: Routledge, pp. 186-203.

Marks, Loren D., and David C. Dollahite. 2017. Religion and Families. New York: Routledge.

Marks, Loren D., Katrina Hopkins, Cassandra Chaney, Pamela A. Monroe, Olena Nesteruk, and Diane D. Sasser. 2008. 'Together, We Are Strong': A Qualitative Study of Happy, Enduring African American Marriages. Family Relations: An Interdisciplinary Journal of Applied Family Studies 57: 172-85. [CrossRef]

Marks, Loren D., David C. Dollahite, and Jeffrey P. Dew. 2009. Enhancing Cultural Competence in Financial Counseling and Planning: Understanding Why Families Make Religious Contributions. Journal of Financial Counseling and Planning 20: 14-26.

Marks, Loren. D., David C. Dollahite, and Joanna Jacob Freeman. 2011. Faith in Family Life. In Successful Marriages and Families: Proclamation Principles and Research Perspectives. Edited by Alan J. Hawkins, David C. Dollahite and Thomas W. Draper. Provo: BYU Studies, pp. 185-95.

Marks, Loren D., Trevan G. Hatch, and David C. Dollahite. 2017. Sacred Practices and Family Processes in a Jewish Context: Shabbat as the Weekly Family Ritual Par Excellence. Family Process 57: 448-61. [CrossRef]

Muslim, Sahih. 1151. Book 13, Hadith 212. Available online: https://sunnah.com/muslim/13/212 (accessed on 12 February 2019).

Pargament, Kenneth I., and Annette Mahoney. 2005. Sacred Matters: Sanctification as a Vital Topic for the Psychology of Religion. International Journal for the Psychology of Religion 15: 179-98. [CrossRef]

Pew. 2007. Muslim Americans: Middle Class and Mostly Mainstream; Washington, DC: Pew Research Center, May. Available online: www.pewresearch.org/2007/05/22/muslim-americans-middle-class-and-mostlymainstream/ (accessed on 12 February 2019).

Pew. 2011. Muslim Americans: No Signs of Growth in Alienation or Support for Extremism; Washington, DC: Pew Research Center, August. Available online: www.people-press.org/2011/08/30/muslim-americans-nosigns-of-growth-in-alienation-or-support-for-extremism/ (accessed on 12 February 2019). 
Pew. 2017a. Why Muslims Are the World's Fastest-Growing Religious Group; Washington, DC: Pew Research Center, April. Available online: www.pewresearch.org/fact-tank/2015/04/23/why-muslims-are-theworlds-fastest-growing-religious-group / (accessed on 12 February 2019).

Pew. 2017b. World's Muslim Population More Widespread than You Might Think; Washington, DC: Pew Research Center, January. Available online: www.pewresearch.org/fact-tank/2013/06/07/worlds-muslimpopulation-more-widespread-than-you-might-think/ (accessed on 12 February 2019).

Piela, Anna. 2010. Muslim Women's Online Discussions of Gender Relations in Islam. Journal of Muslim Minority Affairs 30: 425-35. [CrossRef]

Pieper, Martha H. 1989. The Heuristic Paradigm. Smith College Studies in Social Work 60: 8-34. [CrossRef]

Plauche, Hannah Pearce, Loren D. Marks, and Alan J. Hawkins. 2016. Why We Chose to Stay Together: Qualitative Interviews with Separated Couples Who Chose to Reconcile. Journal of Divorce E Remarriage 57: 317-37.

Read, Jen'nan Ghazal. 2002. Challenging Myths of Muslim Women: The Influence of Islam on Arab-American Women's Labor Force Activity. Muslim World 92: 19. [CrossRef]

Read, Jen'nan Ghazal. 2003. The Sources of Gender Role Attitudes among Christian and Muslim Arab-American Women. Sociology of Religion 64: 207-22. [CrossRef]

Read, Jen'nan Ghazal. 2004. Family, Religion, and Work among Arab American Women. Journal of Marriage and Family 66: 1042-50. [CrossRef]

Robinson, Linda C. 1994. Religious Orientation in Enduring Marriage: An Exploratory Study. Review of Religious Research 35: 207-18. [CrossRef]

Robinson, Linda C., and Priscilla W. Blanton. 1993. Marital Strengths in Enduring Marriages. Family Relations: An Interdisciplinary Journal of Applied Family Studies 42: 38-45. [CrossRef]

Seymour, Julie, Gill Dix, and Tony Eardley. 1995. Joint Accounts: Methodology and Practice in Research Interviews with Couples. New York: Social Research Policy Unit.

Spagnola, Mary, and Barbara H. Fiese. 2007. Family Routines and Rituals: A Context for Development in the Lives of Young Children. Infants \& Young Children 20: 284-99.

Stark, Rodney, and Roger Finke. 2000. Acts of Faith. Berkeley: University of California.

Strauss, Anselm, and Juliet Corbin. 1998. Basics of Qualitative Research. Thousand Oaks: Sage.

Taylor, Robert J., Linda M. Chatters, and Jeff Levin. 2004. Religion in the Lives of African Americans: Social, Psychological, and Health Perspectives. Thousand Oaks: Sage.

Thomas, Darwin L., and Marie Cornwall. 1990. Religion and Family in the 1980s: Discovery and Development. Journal of Marriage \& Family 52: 983-92.

Tiliouine, Habib, Robert A. Cummins, and Melanie Davern. 2009. Islamic Religiosity, Subjective Well-Being, and Health. Mental Health, Religion \& Culture 12: 55-74.

Wilcox, W. Bradford, and Nicholas H. Wolfinger. 2016. Soul Mates: Religion, Sex, Love, and Marriage among African Americans and Latinos. New York: Oxford.

Ziaee, Vahid, M. Razaei, Zahra Ahmadinejad, Hidayatullah Shaikh, R. Yousefi, Lotfollah Yarmohammadi, F. Bozorgi, and M. Javad Behjati. 2006. The Changes of Metabolic Profile and Weight during Ramadan Fasting. Singapore Medical Journal 47: 409-14. [PubMed]

(C) 2019 by the authors. Licensee MDPI, Basel, Switzerland. This article is an open access article distributed under the terms and conditions of the Creative Commons Attribution (CC BY) license (http://creativecommons.org/licenses/by/4.0/). 